\title{
ANALISIS PERSEPSI MASYARAKAT TERHADAP KOMUNITAS PEDULI LUBANG JALANAN KOTA MALANG
}

\author{
Faizal Kurniawan \\ IKIP Budi Utomo Malang \\ faizalkurniamsi@gmail.com
}

\begin{abstract}
AAbstract: Malang City with all its facilities is ancrowded city. As a result the streets in most areas in Malang Raya is becoming frequently used. The density of vehicle volume every day resulted in many holes in the road. However, late handling of the municipal and district governments resulted in more and more potholes in the streets. Of course this results in disappointment for road users. Many victims of accidents caused by falling due to potholes. Not least the victims of this perforated road encourage a group of young people to form a Community Care for the Hole of the Road. This group moves voluntarily. Social counciosness encourages them to form this community. In the action, they make a circular sign or edge with a white pylox against the holes on each road segment. The goal is white as a sign for road users to see the white marka they have created. The sign is felt quite effective because in the distance before the hole, the rider can lower the speed. A lot of appreciation is given to this community. Because by remembering the many holes in the streets of Malang, and the number of "Personal Capital" they have spent for this social action. Their action also received a response from the mayor. This study uses a case study approach and indepth interview method to community members and also a source of road users who recognize the existence of this grassroots community. Observations are made to this community by following all the activities of this group. As a result, people's perception of the two groups is divided into two, the pros and cons of their actions. In the contrary reasoned that the existence of sentences that are not appropriate to be displayed in public facilities. In conclusion, the pro-society perception towards grassroots movements can be a resistance movement for government policies that are slow to deal with this problem. Evidenced by the more intense they carry out the action, the response of the city government and Malang district faster. It is expected that this social awareness will encourage Malang city and district government to be more sensitive to the sound of netizens in both social media and aspirations directly.
\end{abstract}

Keywords: Perception, Mass Communication, Road Community Care

Kota Malang Raya adalah salah satu kota dengan aktivitas yang padat. Hal itu dibuktikan dengan adanya tiga perguruan tinggi, dan 51 perguruan tinggi swasta. Selain itu, banyak tersedianya industri swasta dan badan usaha milik negara di Kota yang berjuluk kota bunga dan kota pendidikan ini. Aktivitas di Malang Raya tentu tidak akan pernah sepi. Selain itu letak geografis kota Malang yang menjadi penghubung antara Surabaya - Sidoarjo - Blitar - Kediri menjadikan Malang Raya menjadi destinasi bagi infestor-infestor yang ingin mengembangkan usahanya.Dalam situs resminya mengatakan,bagian selatan merupakan dataran tinggi yang sering digunakan untuk kawasan industri.Sedangkan bagian utara Malang Raya merupakan dataran tinggi yang subur, sehingga pertanian dan pariwisata Malang Raya terpusat di daerah utara.Sedangkan bagian timur merupakan kawasan perumahan yang padat akan penduduk. Bagian barat Malang Raya adalah kawasan pendidikan.Banyak sekolah maupun perguruan tinggi berdiri di kawasan barat Malang Raya.Selain itu Kota Malang juga berusaha untuk membangkitkan pariwisatanya. Salah satu komitmennya Abah Anton, Walikota Malang, memberikan slogan "Beautifull Malang" untuk menunjang kegiatan ini (Anwar : 2015)

Banyak tersedianya fasilitas di Malang Raya ini mengakibatkan tingginya aktifitas di kota ini. Penggunaan jalan raya sebagai sarana transportasi yang menghubungkan segala tempat di Malang Raya pun tak pernah sepi dalam 24 Jam. Kualitas aspal yang bagus, serta perawatan jalan yang stabil tentu akan menunjang sustaianability. Akan tetapi, apa yang terjadi di Malang Raya adalah banyaknya lubang yang sering dikeluhkan oleh netizen dan masyarakat Malang Raya. Netizen pada media sosialnya, dan pada sebuah grup diskusi media sosial di Facebook memberikan gelar Kota Malang sebagai "WisataLubang Sewu" atau dalam bahasa Indonesianya adalah Wisata 
Lubang Seribu. Tentu ungkapan dalam ruang publik media sosial ini sebagai bentuk social distrust netizen kepada Pemerintah Kota dan Pemerintah Kabupaten yang terkesan lamban dalammasalah jalan berlubang yang ada di Malang Raya.

Menurut Komisi C DPRD Kota Malang, Bambang Sumarto menjelaskan bahwa kualitas aspal jalanan yang dikerjakan oleh dinas pekerjaan umum DPU malang raya tidak bagus. Sebenarnya ada kualitas aspal yang bagus dengan sedikit proses menambahkan pemanasan pada pemasangan aspal. (Hamzah: 2015). Selain kualitas aspal yang kurang memadai, rendahnya sistem drainase Malang Raya terhadap genangan air pada jalan juga menyebabkan aspal jalan di Malang Raya sering mengelupas, (Yayak: 2015). Rendahnya prosesmaintenance jalan di Malang Raya ini mengakibatkan aspal yang rusak itu semakin melebar pada luas jalan.

Lubang pada ruas jalan ini tidak hanya terdapat pada kawasan tertentu di Malang Raya, akan tetapi akibat penanganan yang lambat dari pemerintah kota maupun kabupaten, keberadaan lubang jalan ini semakin merata di kawasan Malang Raya. Dimulai dengan Jalan Laksamana Martadinata yang memang merupakan jalur propinsi, sampai kepada jalur alternatif seperti jalan mayjen sungkono. Walikota Malang, Abah Anton menyadari akan banyaknya jalan di Kota Malang yang memerlukan perbaikan, (Wahyuni: 2017). Menurut Abah Anton, jalan yang perlu mendapatkan perhatian terlebih dahulu adalah kawasan Jalan Panji Suroso, Jalan Ahmad Yani, Jalan Priyo Sudarmo sampai kepada jalan mergosono.

Banyaknya lubang yang diakibatkan rendahnya kualitas aspal mengakibatkan korban jatuh atau kecelakaan lalu lintas.Terutama bagi pengguna sepeda motor.Jatuh ke dalam lubang jalan bagi pengendara sepeda motor mengakibatkan kehilangan keseimbangan sampai pada akhirnya terjatuh.Tidak hanya dikarenakan dengan kecepatan yang tinggi, bahkan dengan kecepatan yang sedang, jika lubang dengan ukuran sedang sampai besar maka bisa mengakibatkan kecelakaan lalu lintas.Seperti kejadian di jalan Bandulan, ada korban akibat kecelakaan tunggal yang disebabkan oleh jalanan yang berlubang
(Indriana : 2016).Selain kecelakaan tunggal yang diakibatkan oleh lubang jalanan.Kerugian pengguna jalan lainnya adalah rusaknya salah satu onderdil kendaraan bermotor seperti velg, lampu, sampai bagian motor yang pecah.Banyaknya korban inilah yang dikeluhkan oleh sebagian besar publik Malang Raya.Timbul semacam social distrust kepada pemerintah dalam soal menangani public facility.

Penanganan yang lambat inilah yang mendorong munculya kepedulian sosial.Mereka berkumpul membentuk suatu kelompok sosial peduli jalanan berlubang di Malang Raya. Mereka memberikan kepeduliannya dengan memberikan tanda dengan menggunakan cat spray atau yang biasa disebut Pylox. Semenjak kegiatan mereka mendapatkan respon positif dari netizen, komunitas ini semakin besar.Dan skala usaha mereka pun meluas, biasanya mencakup kawasan Malang Kota, sekarang sudah sampai merambah ke Kota Batu.

Permasalahan dari penelitian ini adalah bagaimana gambaran umum dari komunitas peduli lubang jalanan Kota Malang ini.Seperti yang kita tahu, bahwa komunitas ini lahir akibat kepedulian mereka terhadap banyaknya jalanan yang berlubang di Malang Raya ini sedangkan jalanan yang berlubang itu lambat mendapat tanggapan dari Kota Malang.Kemudian permasalahn kedua dari penelitian ini adalah bagaimana persepsi masyarakat terhadap keberadaan komunitas ini?

Tujuan dari penelitian ini adalah menjawab semua permasalahan yang telah disebutkan diatas yaitu mengetahui gambaran umum komunitas peduli lubang Kota Malang.Selain itu penelitian ini berfungsi untuk menganalisis persepsi masyarakat terhadap keberadaan komunitas ini.Karena keberadaan komunitas ini tidak hanya mendapatkan reaksi positif, tetapi juga dapat reaksi negatif.

\section{METODE}

Penelitian ini menggunakan metode kualitatif dengan menggunakan pendekatan studi Kasus. Pendekatan studi kasus dilakukan apabila pertanyaan penelitian adalah apa dan mengapa. Menelaah suatu kasus secara mendalam dan intensif, mendalam, mendetail dan komprehensif. Kasus dapat diperoleh dari kasus yang unik, bersifat baru, budaya ilmiah, dan Hoolistik. Langkah penelitian dalam studi 
kasus menurut Denzin $(1994 ; 244)$ yang pertama yaitu membatasi kasus, dalam penelitian ini kasusnya adalah bagaimana persepsi masyarakat terhadap munculnya komunitas peduli lubang. Langkah kedua menurut Denzin adalah menyeleksi fenomenafenomena dalam kasus penelitian ini adalah banyaknya jalanan berlubang di Malang Raya sehingga muncul komunitas akar rumput ini. Tahapan ketiga adalah menentukan pola data untuk mengembangkan isu. Dalam penelitian ini data wawancara yang nantinya akan dikembangkan adalah bagaimana terbentuknya komunitas yang pada akhirnya menjadi sebuah gerakan protes terhadap kebijakan pemerintah dalam memperbaiki jalan yang berlubang.

\section{Tilang, Komunitas Sosial yang Lahir Melalui Kekuatan Dunia Maya}

O'brein (dalam Bungin, 2009) menjelaskan bawa perilaku manusia dan teknologi memiliki kecendrungan untuk masuk ke dalam sosioteknologi. Ada lima komponen perilaku manusia dan teknologi dalam berinteraksi yaitu (1) Struktur Masyarakat, (2) Sistem teknologi informasi, (3) Masyarakat dan Budaya, (4) Strategi Komunikasi dan (5) Proses Sosial. Kaitannya pada kasus terbentuknya Komunitas Tilang ini bermula dari sebuah grup sosialfacebookbernama "Komunitas Peduli (Asli) Malang".Grup diskusi ini sudah terbentuk sejak tahun 2010.Grup diskusi dunia maya, yang sebagai budaya populer ini terbukti sangat ampuh dalam menampung aspirasi netizen yang hampir semuanya berasal dari Malang Raya.Beberapa permasalahan yang berkaitan dengan publik policy atau konflik pribadi dapat diselesaikan melalui pertemuan yang dimulai dari diskusi di ruang publik media sosial ini.Kekecewaan pengguna jalan akibat banyaknya jalan berlubang ditumpahkan melalui media sosial Komunitas Peduli (Asli) Malang ini.Pada awalnya tiap-tiap pengguna jalan mengeluhkan kebanyakan jalan di Kota Malang yang rusak, sampai jatuh korban kecelakaan lalu lintas.Curhatan netizen yang diwadahi oleh grup sosial facebook "Komunitas Peduli (Asli) Malang"tentang jatuhnya korban yang jatuh semakin hari semakin banyak.Terhitung setiap hari rata-rata dua kasus yang dikeluhkan netizen di "Komunitas Peduli (Asli) Malang".
Seringnya keluhan kecelakaan tunggal yang diceritakan di media sosial inilah yang mendorong sebagian orang untuk melaksanakan aksinya untuk membentuk suatu komunitas agar melakukan suatu respon terhadap kasus jalan berlubang. Satu orang bernama Bayu yang memulai aksinya dengan memberikan tanda lingkaran dengan menggunakan cat spray warna putih sebagai tanda bahwa disitu terdapat lubang.Pembuatan tanda dengan lubang ini dapat terasa effect nya.Pada malam hari, tanda ini sangat terasa bedanya.

Kegiatan mereka berlangsung pada malam hari, mereka berkumpul di suatu tempat untuk merencanakan aksi sosial mereka.Pemilihan waktu malam hari adalah karena banyak anggota dari komunitas ini sudah bekerja atau kuliah, malam hari adalah waktu yang pantas untuk melaksanakan aksi mereka.Selain karena pada waktu malam yang mempertemukan mereka dari kesibukan masing, masing, adalah karena pada malam hari keamanan di jalan cukup senggang, hal ini mendorong mereka memilih waktu malam untuk menjalankan aksinya.Sejauh ini dalam melaksanakan aksinya, kelompok ini masih belum pernah mendapatkan konflik fisik dengan yang menentang aksi mereka.Konflik yang mereka alami hanyalah cibiran-cibiran pengguna media sosial yang tidak sependapat dengan aksi mereka.Meskipun tergolong pergerakan bawah tanah, akan tetapi komunitas ini mulai dilirik oleh media televisi skala nasional.

Setelah melaksanakan aksinya Bayu mengupload foto-foto kegiatannya ke dalam Grub "Komunitas Peduli (Asli) Malang". Bayu mengakuiapa yang telah dia lakukan untuk mendapatkan pengakuan sosial bahwa dirinya adalah salah satu orang yang berbuat sebagai bentuk kepedulian terhadap kota Malang.Strategi komunikasi ini dirasak an berhasil, karena banyak netizen yang memberikan respon positif. Dengan adanya respon-respon positif inilah yang mendukung netizen lain untuk ikut berpartisipasi terhadap aksi dari Bayu tersbut. Sinergi kepentingan yang sama yaitu menghendaki adanya pengakuan sosial dan kepedulian sosial terhadap kota Malang.Semakin lama keberadaan komunitas peduli lubang ini semakin dirasakan eskistensinya, jumlah anggotanya pun semakin banyak. Media komunikasi massa Grub 
"Komunitas Peduli (Asli) Malang" membuat komunitas ini semakin popular. Bayu juga mengaku sudah banyak media yang meliputnya

\section{Komunikasi Massa yang Melahirkan Social Consciusness}

Komunitas sosial Tilang lahir dari serangkaian komunikasi massa melalui media online di grup facebook "Komunitas Peduli (Asli) Malang". Secara sederhana komunikasi massa berarti pesan yang dikomunikasikan pada sejumlah orang dalam jumlah besar melalui media massa atau media sosial (Rakhmat : 188). Katika individu memberikan informasi atau sekedar berkeluh kesah, maka orang lain melihat respon, maka terjadilah proses komunikasi. Komunikasi tersebut tentunya akan menimbulkan efek, menurut Karlinah dan kawan-kawan (2009:52) komunikasi di media massa atau media sosial dapat menimbulkan efek-efek Kognitif, efek afektif, dan efek behavorial. Efek kognitif adalah efek akibat yang timbul pada diri komunikan yang sifatnya informative bagi dirinya. Dalam efek kognitif akan dibahas tentang bagaimana media massa dan media sosial dapat membantu khalayak mempelajari informasi yang bermanfaat dalam mengembangkan kemampuan kognitifnya. Efek kognitif terjadi apabila ada yang diketahui dan difahami, atau diapresiasi oleh khalayak.Untuk Efek afektif, kondisinya lebih tinggi bila dibandingkan dengan efek kognitif. $\mathrm{T} \mathrm{u} \mathrm{j} \mathrm{u} \mathrm{a} \mathrm{n}$ dari komunikasi massa bukan sekedar memberitahu khalayak akan sebuah informasi, akan tetapi penerima respons akan dapat bisa merasa terharu, iba gembira, marah dan sebagainya. Sedangkan efek behavorial merupakan akibat dari dampak yang berupa perilaku ketika menerima respons dari komunikan.

Pada kasus dalam penelitian ini, bahwa terbentuknya komunitas Tilang itu sudah sampai pada tahapan efek afektif, pembentukan komunitas berdasarkan kesadaran dan kesamaan respons masyarakat yang tegabung dalam komunikasi massa di grup facebook "Komunitas Peduli (Asli) Malang". Gerakan menandai jalan memang dimulai oleh Bayu, namun akibat dia mempublikasikan, dia menginginkan sebuah pengakuan publik kepada dirinya inilah yang mengakibatkan komunitas Tilang ini berkembang.Selain itu kegiatan sosial ini membutuhkan sebuah legitimasi masyarakat untuk dapat sustainable.

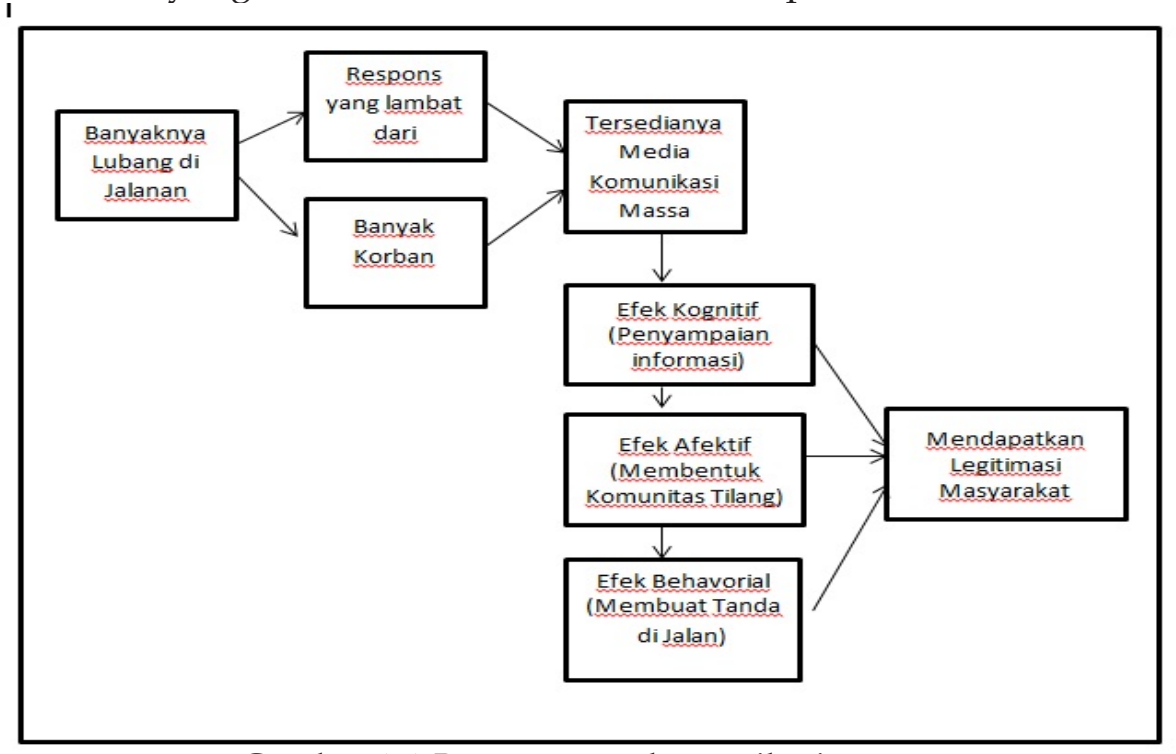

Gambar 1.1 Bagan proses komunikasi massa

Dalam hal ini kesadaran sosial atau Social Consciusnesslahir pada tahapan afektif.Hanya saja bedanya dengan legitimasi masyarakat, proses legitimasi masyarakat bisa berlangsung pada ketiga tahap yaitu tahap kognitif, tahap afektif, dan tahap behavorial. Karena masyarakat pada kasus banyaknya lubang di kota malang cenderung memberikan apresiasi sejak proses netizen atau masyarakat melaporkan banyaknya lubang pada media komunikasi massa yang disini adalah grup facebook "Komunitas Peduli (Asli) Malang".Berkumpulnya sekelompok orang yang peduli terhadap fasilitas umum yang rusak disini lah yang mendorong terbentuknya komunitas Tilang yang dipelopori oleh Bayu.Perbincangan dan persoalan tentang 
kesadaran sosial ini adalah merupakan masalah klasik.Kesadaran yang bermula dari kesadaran individu inilah yang berkembang menjadi kesadaran sosial.Pada dasarnya grup facebook "Komunitas Peduli (Asli) Malang" adalah sebagai ruang publik yang dilegitimasi masyarakat pengguna sosial media sebagai salah satu media komunikasi massa untuk halhal kepentingan masyarakat Kota Malang.Kesadaran sosial ini timbul dengan sendirinya, apalagi setelah ada korban berjatuhan. Kesadaran sosial masyarakat timbul dengan bantuan media komunikasi massa. Media tersebut menggugah Social Consciusnessagar tiap netizen ikut berpartisipasi kegiatan pembentukan komunitas Tilang ini.

\section{Analisis Persepsi Masyarakat}

Publik Malang Raya mengenal komunitas peduli lubang melalui grup facebook “Komunitas Peduli (Asli) Malang. Mengenal komunitas ini tentu akan menghasilkan persepsi beragam. Rahmat (2005) mengemukakan bahwa dua jenis persepsi tersebut adalah persepsi positif dan negatif. Apabila suatu hal yang dipersepsi sesuai dengan penghayatan dan dapat diterima secara rasional dan emosional maka seorang akan mempersepsikan secara positif, namun apabila tidak memenuhi dengan kriteria tersebut maka akan cenderung menjauhi, menolak, dan menanggapi secara berlawan objek persepsi tersebut. Persepsi positif merupakan penilaian individu terhadap suatu objek, sesuai Dalam analisis frekuensi yang didapat adalah :

\begin{tabular}{|c|c|c|c|}
\hline No & Persepsi & $\%$ & Alasan \\
\hline 1 & Positif & 80 & $\begin{array}{l}\text { 1. Jalan adalah fasilitas publik, kepedulian } \\
\text { terhadap fasilitas umum tentu memberikan } \\
\text { pesan positif } \\
\text { 2. Banyaknya korban jatuh mengakibatkan } \\
\text { dukungan terhadap keberadaan komunitas ini } \\
\text { 3. Kecintaan terhadap kota Malang, mendorong } \\
\text { seseorang untuk tetap mendukung eksi stensi } \\
\text { komunitas Tilang } \\
\text { 4. Penanganan yang lambat dari pemerintah } \\
\text { menandakan terbentuknya komunitas ini } \\
\text { sebagai bentuk perlawanan }\end{array}$ \\
\hline 2 & Negatif & 20 & $\begin{array}{l}\text { 1. Aksi yang tidak memberikan solusi } 100 \% \text { ini } \\
\text { memberikan anggapan bahwa hal ini adalah } \\
\text { perbuatan yang sia-sia } \\
\text { 2. Sekilas memang aksi ini mirip vandalism } \\
\text { yang pernah meresahkan warga malang } \\
\text { trauma juga mempengaruhi persepsi negatif } \\
\text { masyarakat } \\
\text { 3. Penggunaan kalimat -kalimat kasar dan tidak } \\
\text { pantas mengurangi kepercayaan masyarakat } \\
\text { terhadap eksistensi komunitas ini }\end{array}$ \\
\hline
\end{tabular}

Tabel 1.1 Persentase persepsi responden

Dari keseluruhan responden, memang tingkat kepuasan masyarakat Malang Raya dan netizen pengguna media komunikasi massa memang cenderung simpatik dan mendukung eksistensi komunitas sosial ini. Masyarakat berpikir, kalau tidak ada komunitas ini lalu siapa yang bersedia melakukan aksi sosial ini.Masyarakat menaikkan rating komunitas ini dengan aktif memberikan respons positif di media sosial maupun dalam pelaksanaan di dunia nyata.Masyarakat juga menyadari bahwa dukungan mereka akan membuat komunitas ini akan tetap hidup. Apresiasi dukungan juga sebagai bentuk kekecewaan masyarakat malang raya yang rajin membayar pajak, akan tetapi pemerintah kota dan kabupaten yang bergerak lamban menangani keluhan-keluhan masyarakat. 
Selain dukungan yang bersifat menaikkan rating, masyarakat malang raya juga memberikan bantuan cat semprot (Pylox). Mereka sadar tidak mempunyai cukup waktu untuk bergabung dengan komunitas ini, namun masyarakat ikut mendukung aksi mereka dengan memberikan segala macam logistic keperuan untuk komunitas ini melaksanakan aksinya.

\section{KESIMPULAN}

Komunitas Tilang atau komunitas peduli lubang jalanan kota malang memulai aksinya melalui seorang individu, dimulai dari kesadararan individu, kemudian individu mengunggahnya ke media sosial dalam rangka untuk mendapatkan pengakuan publik. Budi selain peduli, dia ingin mendapatkan popularitas dan pengakuan dari publik melalui aksinya.Budi semakin bersemangat ketika aksinya mendapatkan dukungan moril dari masyarakat, terutama dari kalangan netizen.Komunitas terbentuk dikarenakan kesamaan persepsi bahwa jalanan yang berlubang perlu mendapatkan perhatian dari pemerintah.Pemerintah disini berperan sebagai bentukan dominasi, kaum dominan enggan merespon suara dari masyarakat.Masyarakat melakukan aksi perlawanan dengan bentuk sindiran yaitu dengan menandai jalan yang berlubang dengan pylox putih.Meski aksi mereka tidak sepenuhnya membuahkan solusi, setidaknya melalui aksi ini memberikan peringatan bahwa pergerakan itu melalui akar rumput.Komunitas Tilang hadir sebagai perlawanan akar rumput yang dimulai dari masyarakat bawah. Komunitas ini akan selalu mendapatkan legitimasi masyarakat, meskipun aksi mereka bukan merupakan solusi sampai selesai, namun aksi mereka merupakan aksi progressive yang membuat pemerintah kota bergerak. Respon pemerintah positif terhadap keberadaan komunitas ini.

Pemerintah kota dan kabupaten malang hendaknya merespon cepat dan segera melaksanakan perbaikan menyeluruh terhadap permasalahan yang berhubungan dengan fasilitas publik ini. Pergerakan sosial yang dimulai dari kesadaran sosial inilah yang seharusnya menggerakkan pemerintah agar melakukan maintenance dengan cepat. Respon yang lambat dari pemerintah dan penundaan maintenance hanya akan berakibat bertambahnya korban akibat jalanan yang rusak. Komunitas Tilang juga perlu menjaga nama baik dan eksistensi mereka dengan menggunakan kalimat-kalimat positif dalam coretan mereka. Sehingga perspektif masyarakat yang negatif dapat berkurang

\section{DAFTAR RUJUKAN}

\section{Buku}

Ardianto, E., Lukiati, K. dan Siti, K. 2009, Komunikasi Massa, Bandung, Simbiosa Rekatama Media.

Bungin, B. P. Sosiologi Media, Komunikasi Sosial, Teknologi Informatika, Kebudayaan Seks di Media Massa. Prenada Media Group, Bandung.

Denzin, N. K. dan Lincoln, Y. S. (Eds), 1994. The Handbook of Qualitative Research Thousand Oaks, CA: Sage

Rakhmad, J. 1994. Psikologi Komunikasi, Bandung, Remaja Rosdakarya

\section{Internet :}

Anwar, K. http://www.malangtimes.com/ baca/3365/20150823/174547/hari-iniabah-anton-resmi-melaunching-beautifulmalang-/ diakses 12 Februari 2017, 06.30

Hamzah, M. N. http://malangvoice.com/ aspal-mudah-rusak-bambang-kualitasnyajelek/, Diakses 12 Februari 2017, 21.00

Indriana, M. https:/ / malangtoday.net/malangraya/banyak-warga-terjatuh-akibat-jalanrusak-di-bandulan/ Diakses 12 Februari 2017, 20.00

Yayak. 2015 http://radarmalang.co.id/barusebulan-aspal-mengelupas-25271.htm, Diakses 12 Februari 2017 Pukul 07.00

Wahyuni. http:// suryamalang.tribunnews.com/2017/02/ 07/2018-target-perbaikan-jalan-berlubangdi-kampung-di-kota-malang-harus-selesai, Diakses 6 Februari 2017 
Faisal, Analisis Persepsi Masyarakat .... ॥19 